\title{
Substitusi tepung kacang hijau (Vigna radiata) dan tepung ikan tuna (Thunnus sp) sebagai biskuit PMT ibu hamil terhadap kadar proksimat, nilai energi, kadar zat besi, dan mutu organoleptik
}

\author{
Substitution of Mung Bean Flour (Vigna Radiata) and Tuna Flour (Thunnus sp) as Pmt Biscuits \\ for Pregnant Women on Proximate Levels, Energy Values, Iron Levels, and Organoleptic
}

Quality

\author{
Miftahul Roifah ${ }^{1)}$, Maryam Razak ${ }^{1)}$, I Komang Suwita ${ }^{1)}$ \\ ${ }^{1}$ Jurusan Gizi, Politeknik Kesehatan Kemenkes Malang \\ Email: maryamrazak0811@gmail.com \\ Informasi Artikel: \\ Dikirim: 30/08/2019; ditinjau: 31/08/2019; disetujui: 30/09/2019
}

\begin{abstract}
Nutrition problems in Indonesia are focused on the First 1000 Days of Life, which starts from the fetus in the mother's womb to toddlers aged 2 years. The targets to be intervened in this study are pregnant women. Where generally pregnant women have disorders such as anemia and Chronic Energy Deficiency. The disorder can be prevented by providing additional food using local ingredients. The purpose of this study was to obtain the right formulation of green bean flour biscuits and tuna flour for pregnant women PMT. This study uses a laboratory experimental research design with a completely randomized design study (CRD) using 3 levels of treatment, as many as 9 experimental units. $P 1$ treatment level with the proportion of wheat flour: mung bean flour: tuna flour (75:15:10), P2 (65: 29: 6), and P3 (55: 41: 4). The results showed the substitution of mung bean flour and tuna flour had a significant influence on water content, ash content, protein content, fat content, iron content, aroma of biscuits. However, it gives no significant effect on carbohydrate levels. color, taste and texture. $P 2$ treatment level is the best treatment.
\end{abstract}

Keywords: mung bean flour, tuna flour, pregnant biscuits, proximate content, organoleptic quality

\begin{abstract}
ABSTRAK
Masalah gizi di Indonesia di fokuskan pada 1000 Hari Pertama Kehidupan, yang dimulai dari janin dalam kandungan ibu sampai balita umur 2 tahun. Sasaran yang akan di intervensi dalam penelitian ini adalah ibu hamil. Dimana umumnya ibu hamil memiliki gangguan seperti anemia dan KEK (Kekurangan Energi Kronis). Gangguan tersebut bisa dicegah dengan memberikan makanan tambahan dengan menggunakan bahan lokal. Tujuan penelitian ini adalah untuk mendapat formulasi yang tepat biskuit tepung kacang hijau dan tepung ikan tuna untuk PMT ibu hamil. Penelitian ini menggunakan jenis penelitian eksperimen laboratorium dengan desain penelitian Rancangan Acak Lengkap (RAL) menggunakan 3 taraf perlakuan, sebanyak 9 unit percobaan. Taraf perlakuan P1 dengan proporsi tepung terigu : tepung kacang hijau : tepung ikan tuna $(75: 15: 10)$, P2 $(65: 29: 6)$, dan P3 $(55: 41: 4)$. Hasil penelitian menunjukkan Substitusi tepung kacang hijau dan tepung ikan tuna memberikan pengaruh yang signifikan terhadap kadar air, kadar abu, kadar protein, kadar lemak, kadar zat besi, aroma biskuit. Namun memberikan pengaruh yang tidak signifikan
\end{abstract}


terhadap kadar karbohidrat. warna, rasa, dan tekstur. Taraf perlakuan P2 merupakan perlakuan terbaik.

Kata kunci: tepung kacang hijau, tepung ikan tuna, biskuit ibu hamil, kadar proksimat, mutu organoleptik.

\section{PENDAHULUAN}

Masa kehamilan merupakan periode sensitif 1000 HPK yang harus di optimalkan untuk perkembangan sel-sel otak manusia. Keberhasilan kesehatan ibu hamil dapat dilihat dari indikator Angka Kematian Ibu (AKI) yang meliputi jumlah kematian ibu selama kehamilan, persalinan, dan nifas. Berdasarkan SUPAS (2015) angka kematian ibu hamil di Indonesia sebesar 305 per 100.000 kelahiran hidup, persentase ini tergolong tinggi dibandingkan standar WHO dalam program MDGs yaitu sebesar 102 per 100.000 kelahiran hidup. Penyebab terbesar kematian ibu adalah pendarahan sebesar $30,3 \%$, sedangkan faktor utama pendarahan pada ibu hamil adalah KEK (Kekurangan Energi Kronis) dan anemia (Kemenkes RI, 2016). Prevelensi KEK pada ibu hamil di Indonesia juga tergolong tinggi yaitu sebesar 17,3\% (Kemenkes RI, 2018). Prevelensi anemia di Indonesia sebesar $37,1 \%$ pada tahun 2016, dan meningkat pada tahun 2018 sebesar 48,9\% (Kemenkes RI, 2018).

Ketika ibu hamil status gizinya kurang dan mengalami anemia maka akan mempengaruhi pertumbuhan, pembentukan, dan perkembangan janin menjadi kurang optimal. Hal ini akan berdampak cacat bawaan pada bayi dan kematian bayi karena BBLR (Dewi, Pujiastuti dan Fajar, 2013). Salah satu dampak jangka panjangnya adalah balita atau baduta yang dilahirkan akan mengalami stunting, dan memiliki tingkat kecerdasan yang tidak optimal, menjadi lebih rentan terhadap penyakit serta dapat menghambat pertumbuhan ekonomi (Kemenkes RI, 2017). Kejadian stunting juga disebabkan oleh ibu dengan status gizi kekurangan energi kronis (ibu hamil KEK). Hal ini dibuktikan oleh Ningrum (2017), bahwa ada hubungan antara ibu hamil KEK dengan panjang badan bayi baru lahir, yaitu mempunyai kemungkinan 6,2 kali memiliki panjang badan bayi lebih pendek dibanding ibu tidak KEK. Selanjutnya Sukmawati et al. (2018) menyatakan bahwa ada hubungan signifikan antara berat badan lahir bayi dengan kejadian stunting.

Mengingat dampak kurang gizi yang sangat luas, maka perlu upaya penanggulangan gizi ibu hamil. Melalui intervensi yang dapat dilakukan dalam berbagai bentuk salah satunya adalah dengan pemberian makanan tambahan berbentuk biskuit.

Pemberian makanan tambahan (PMT) ditunjukkan untuk memenuhi 10\% kebutuhan ibu hamil, dengan kandungan zat gizi sebesar $255 \mathrm{Kkal}$, 7,6 gram protein, 8,5 gram lemak dan 3,9 mg Fe (Depkes RI, 2013). Pemberian makanan tambahan ini sudah ada dalam program intervensi yang ditetapkan oleh Kementerian Kesehatan untuk ibu hamil KEK. Pemberian makanan tambahan tersebut dengan bentuk biskuit lapis yang berbahan dasar utama tepung terigu atau tepung gandum. Namun dalam hal ini, perlu diversifikasi pangan berbasis produk lokal untuk mengurangi ketergantungan akan produk olahan impor seperti tepung terigu dan gandum. Diversifikasi pangan berbasis lokal dilakukan dengan suplementasi pangan, yang memerlukan bahan lokal serta kaya kandungan gizi mikro dan makro untuk memenuhi kebutuhan ibu hamil. Berdasarkan hasil penelitian Putri et al. (2019) yang memberikan biskuit berbasis pangan lokal selama 90 hari dapat meningkatkan berat badan dan LiLA ibu hamil KEK.

Bahan pangan lokal yang bisa dijadikan sebagai bahan subtitusi PMT ibu hamil adalah bahan pangan lokal yang tinggi protein dan zat besi seperti kacang hijau dan ikan tuna. Kacang hijau dan ikan tuna dapat menjadi bahan dasar dalam pembuatan biskuit ibu hamil. Hal ini karena kacang hijau dan ikan tuna memiliki energi dan 
protein yang tinggi yang berperan penting untuk sel, pertumbuhan dan perkembangan janin serta meningkatkan status gizi ibu. Kacang hijau dan ikan tuna kaya akan zat besi heme dan non heme yang saling melengkapi, hal ini sangat penting untuk pembentukan hemoglobin. Ikan tuna tinggi asam lemak omega 3 yang penting untuk proses tumbuh kembang sel saraf dan sel otak janin serta dapat berperan sebagai simpanan ibu untuk masa persalinan (Ide, 2013).

Adapun pemilihan biskuit sebagai makanan tambahan karena kadar air biskuit rendah dan biskuit bertekstur kering (Almatsier, 2010), dan umumnya biskuit banyak disukai oleh masyarakat. Selain itu biskuit disajikan dalam porsi kecil dan bisa diberikan sering untuk makanan selingan ibu hamil.

Berdasarkan uraian diatas perlu dilakukan penelitian untuk menganalisa pengaruh substitusi tepung kacang hijau dan tepung ikan tuna terhadap kadar proksimat, kadar zat besi, mutu organoleptik, dan taraf perlakuan terbaik. Diharapkan penelitian ini mampu mendapatkan formulasi yang tepat dengan substitusi tepung kacang hijau dan tepung ikan tuna untuk Biskuit PMT untuk ibu hamil.

\section{METODE PELAKSANAAN}

Penelitian ini menggunakan jenis penelitian eksperimen laboratorium dengan desain penelitian Rancangan Acak Lengkap (RAL) menggunakan 3 taraf perlakuan, sebanyak 9 unit percobaan, dengan Proporsi (\%) Tepung Terigu: Tepung kacang hijau : tepung ikan tuna yaitu $\mathrm{P}_{1}(75: 15: 10) ; \mathrm{P}_{2}$ $(65: 29: 6) ; \mathrm{P}_{3}(55: 41: 4)$. Pengembangan formulasi ini di desain untuk memenuhi $10 \%$ kebutuhan gizi ibu hamil berdasarkan AKG 2013, energi $255 \mathrm{Kkal}$, Protein 7,6 gram, Lemak 8,5 gram, dan zat besi 4-15 mg.

\section{Metode Penelitian Pendahuluan}

1. Menentukan Kebutuhan

Sasaran dalam penelitian ini adalah ibu hamil. Menentukan kebutuhan ibu hamil dalam sehari untuk porsi makanan tambahan dengan kepadatan energi 4,5 $\mathrm{Kkal} /$ gram.

2. Menentukan Proporsi

Menentukan proporsi biskuit untuk makanan tambahan berdasarkan nilai energi dan mutu kimia yang ditetapkan untuk ibu hamil.

3. Pembuatan Biskuit Pendahuluan

Hal ini bertujuan untuk menetapkan standar bahan dan metode yang sesuai dalam pembuatan biskuit PMT ibu hamil dengan substitusi tepung kacang hijau dan tepung ikan tuna.

\section{Penepungan kacang hijau}

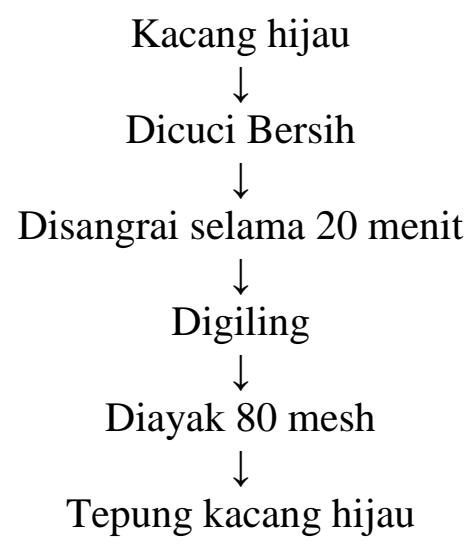

Gambar 1. Diagram Alir Penepungan Kacang Hijau

(Sumber: Sidabutar, 2013) 


\section{Penepungan ikan tuna}

Ikan tuna

Pembersihan, pencucian, pengecilan ukuran, serta pembuangan tulang dan kepala ikan.

Ikan tuna direndam dalam air lemon + jahe yang sudah dihaluskan selama 6 jam dan dengan perbandingan ikan tuna : air lemon: jahe $(1: 1 / 2: 1)$

Dikukus selama 10-15 menit

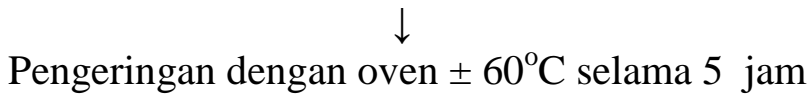

$\downarrow$
Penggilingan dengan blender

$\stackrel{\downarrow}{\downarrow}$ Pengayakan 80 mesh

$\stackrel{\downarrow}{\downarrow}$ Tepung ikan tuna

Gambar 2 Diagram Alir Penepungan Ikan Tuna

(Nurdiani, 2003) dengan modifikasi

\section{Pengolahan biskuit}

Untuk pembuatan biskuit dari tepung kacang hijau dan tepung ikan tuna dalam penelitian ini telah ditetapkan urutan pembuatan biskuit sebagai berikut:

a. Kuning telur, gula halus, margarin, dan susu bubuk full krim, vanili, baking powder diaduk dengan mixer sampai rata selama 15-20 menit sampai berwarna putih.

b. Setelah tercampur rata ditambahkan dengan campuran tepung terigu + tepung kacang hijau + tepung ikan tuna.

c. Diaduk merata kemudian dibentuk pipih dengan ketebalan $3 \mathrm{~mm}$ lalu dilakukan pencetakan. d. Dipanggang ke dalam oven $160^{\circ} \mathrm{C}$ selama 15 menit

\section{Metode analisis}

Poksimat (AOAC,2005), karbohidrat (by different), energi (at water), zat besi (AAS), Organoleptik (Soekarto, 1985)

\section{HASIL PEMBAHASAN}

\section{Deskripsi biskuit}

Dalam penelitian ini, Biskuit PMT Ibu hamil disubstitusikan dengan tepung kacang hijau dan tepung ikan tuna. Biskuit PMT yang dihasilkan berbentuk persegi panjang dengan ukuran $5 \times 3 \mathrm{~cm}$, ketebalan $3 \mathrm{~mm}$ dan berat $6,5 \mathrm{gram} /$ biskuit. 
Tabel 1. Karakteristik biskuit PMT Ibu Hamil

\begin{tabular}{|c|c|c|c|c|c|}
\hline \multirow{2}{*}{$\begin{array}{l}\text { Taraf Perlakuan } \\
\text { (Tepung Terigu: } \\
\text { Tepung Kacang } \\
\text { Hijau : Tepung Ikan } \\
\text { Tuna }\end{array}$} & \multirow[b]{2}{*}{ Gambar } & \multicolumn{4}{|c|}{ Mutu Organoleptik } \\
\hline & & Warna & Aroma & Rasa & Tekstur \\
\hline $\mathrm{P}_{1}(75: 15: 10)$ & & $\begin{array}{l}\text { Kuning } \\
\text { kehijauan } \\
(+)\end{array}$ & $\begin{array}{l}\text { Aroma } \\
\text { amis } \\
\text { ikan } \\
\text { tuna } \\
\text { sedikit } \\
\text { terasa, } \\
\text { aroma } \\
\text { khas } \\
\text { kacang } \\
\text { hijau } \\
(+)\end{array}$ & $\begin{array}{l}\text { Gurih, } \\
\text { manis, } \\
\text { ada rasa } \\
\text { khas } \\
\text { kacang } \\
\text { hijau (+) }\end{array}$ & $\begin{array}{l}\text { renyah } \\
(++)\end{array}$ \\
\hline$(65: 29: 6)^{P_{2}}$ & & $\begin{array}{l}\text { Kuning } \\
\text { kehijauan } \\
(+)\end{array}$ & $\begin{array}{l}\text { Aroma } \\
\text { amis } \\
\text { ikan } \\
\text { tuna } \\
\text { tidak } \\
\text { terasa, } \\
\text { Aroma } \\
\text { khas } \\
\text { kacang } \\
\text { hijau } \\
(++) \\
\end{array}$ & $\begin{array}{l}\text { Gurih, } \\
\text { manis, } \\
\text { ada rasa } \\
\text { khas } \\
\text { kacang } \\
\text { hijau } \\
(++)\end{array}$ & $\begin{array}{l}\text { renyah } \\
(++)\end{array}$ \\
\hline $\mathrm{P}_{3}(55: 41: 4)$ & & $\begin{array}{l}\text { Kuning } \\
\text { kehijauan } \\
(++)\end{array}$ & $\begin{array}{l}\text { Aroma } \\
\text { amis } \\
\text { ikan } \\
\text { tuna } \\
\text { tidak } \\
\text { terasa, } \\
\text { khas } \\
\text { kacang } \\
\text { hijau } \\
(+++)\end{array}$ & $\begin{array}{l}\text { Gurih, } \\
\text { manis, } \\
\text { ada rasa } \\
\text { khas } \\
\text { kacang } \\
\text { hijau } \\
(++)\end{array}$ & $\begin{array}{l}\text { renyah } \\
(+)\end{array}$ \\
\hline
\end{tabular}

Keterangan:

1. Tanda (+) pada kolom warna menunjukkan warna kuning kehijauan, dan tanda (++) menunjukkan warna kuning kehijauan lebih pekat.

2. Tanda (+) pada kolom aroma menunjukkan bahwa aroma khas kacang hijau tidak pekat, tanda (++) menunjukkan aroma khas kacang hijau pekat, tanda (+++) menunjukkan aroma khas kacang hijau sangat pekat.

3. Tanda (+) pada kolom rasa menunjukkan rasa khas kacang hijau terasa, tanda (++) menunjukkan rasa khas kacang hijau sangat terasa.

4. Tanda (+) pada kolom tekstur menunjukkan kurang renyah, tanda (++) menunjukkan tekstur biskuit renyah. 


\section{Kadar proksimat}

Tabel 2. Kadar Proksimat biskuit dalam 100 gram biskuit

\begin{tabular}{lccc}
\hline \multicolumn{1}{c}{ Kadar Zat Gizi } & $\begin{array}{c}\text { P1 } \\
(\mathbf{7 5 : 1 5 : 1 0 )}\end{array}$ & $\begin{array}{c}\text { P2 } \\
\mathbf{6 5 : 2 9 : 6 )}\end{array}$ & $\begin{array}{c}\text { P3 } \\
(\mathbf{5 5 : 4 1 : 4 )}\end{array}$ \\
\hline Kadar Air (gram) & $3,8^{\mathrm{a}}$ & $2,6^{\mathrm{b}}$ & $2,7^{\mathrm{b}}$ \\
Kadar Abu (gram) & $2,2^{\mathrm{a}}$ & $2,4^{\mathrm{ab}}$ & $2,7^{\mathrm{b}}$ \\
Kadar Protein (gram) & $10,7^{\mathrm{a}}$ & $11,4^{\mathrm{ab}}$ & $11,7^{\mathrm{b}}$ \\
Kadar Lemak (gram) & $13,9^{\mathrm{a}}$ & $12,7^{\mathrm{b}}$ & $12,6^{\mathrm{b}}$ \\
Kadar Karbohidrat (g) & $70,5^{\mathrm{a}}$ & $70,1^{\mathrm{a}}$ & $69,9^{\mathrm{a}}$ \\
Nilai Energi (kkal) & $450^{\mathrm{a}}$ & $440,8^{\mathrm{b}}$ & $439,9^{\mathrm{b}}$ \\
Kadar Zat Besi (mg) & $19,7^{\mathrm{a}}$ & $21,6^{\mathrm{b}}$ & $22,3^{\mathrm{b}}$ \\
\hline
\end{tabular}

\section{Kadar air}

Kadar air biskuit PMT Ibu Hamil berkisar antara 2,6-3,8 gram/ 100 gram biskuit. Kadar air tersebut telah memenuhi syarat kadar air biskuit berdasarkan mutu biskuit SNI No. 01-2973-1992 yaitu tidak lebih dari 5 gram/100 gram biskuit.

Kadar air biskuit ibu hamil yang tertinggi adalah P1 sebesar 3,8 gram/100 gram biskuit, sedangkan kadar air biskuit yang paling rendah adalah P2 sebesar 2,6 gram/100 gram biskuit. Berdasarkan hasil analisis statistik One Way Anova pada tingkat kepercayaan $95 \%$ menunjukkan bahwa substitusi tepung kacang hijau dan tepung ikan tuna memberikan pengaruh yang signifikan $(p=0,011)$ terhadap kadar air biskuit. Analisis lebih lanjut dengan Duncan Multiple Range Test menunjukkan bahwa terdapat perbedaan yang signifikan antara biskuit $\mathrm{P} 1$ dengan $\mathrm{P} 2 \quad(\mathrm{p}=0,015)$, dan $\mathrm{P} 1$ dengan P3 ( $p=0,019)$.

Biskuit yang memiliki proporsi tepung terigu yang paling banyak memiliki kadar air yang paling tinggi, hal ini karena kadar tepung terigu memiliki kadar air lebih tinggi daripada kadar air tepung kacang hijau dan tepung ikan tuna, sedangkan semakin banyak proporsi penambahan tepung kacang hijau maka kadar air semakin menurun. Penurunan kadar air terjadi akibat adanya mekanisme pati dan protein, menyebabkan air tidak lagi dapat diikat dengan maksimum. Ikatan hidrogen yang terbentuk antara molekul pati dengan air akan berkurang dengan adanya interaksi pati dan protein (Komah dan Kristiastuti, 2013). Menurut Susanto dan Saneto (1994) kadar air tepung terigu (yaitu
$12 \mathrm{~g} / 100 \mathrm{~g}$ bahan) lebih besar dibandingkan dengan kadar air tepung kacang hijau yaitu $5,07 \mathrm{~g} / 100 \mathrm{~g}$ bahan, sehingga kadar air biskuit cenderung tinggi pada taraf perlakuan dengan proporsi tepung terigu paling banyak (P1). Hal tersebut sejalan dengan penelitian Ratnasari et al. (2015) bahwa biskuit substitusi tepung kacang hijau dengan proporsi yang paling sedikit memiliki kadar air yang paling tinggi. Selain itu biskuit dengan proporsi tepung ikan tuna lebih banyak tidak mempengaruhi kadar air biskuit, hal ini dikarenakan menurut Sahril et al. (2015) tepung ikan tuna memiliki kadar air yang lebih rendah yaitu 9,61 gram/ 100 gram bahan dibandingkan dengan tepung terigu.

\section{Kadar abu}

Kadar abu biskuit PMT Ibu Hamil berkisar antara 2,2-2,7 gram/ 100 gram biskuit. Kadar abu tersebut berbeda dengan standar kadar abu biskuit berdasarkan mutu biskuit SNI No. 01-2973-1992 yaitu tidak lebih dari 2 gram/100 gram biskuit.

Kadar abu biskuit ibu hamil yang tertinggi adalah P3 sebesar 2,7 gram/100 gram biskuit, sedangkan kadar abu biskuit yang paling rendah adalah P1 sebesar 2,2 gram/100 gram biskuit. Berdasarkan hasil analisis statistik One Way Anova pada tingkat kepercayaan $95 \%$ menunjukkan bahwa substitusi tepung kacang hijau dan tepung ikan tuna memberikan pengaruh yang signifikan $(p=0,017)$ terhadap kadar abu biskuit. Analisis lebih lanjut dengan Duncan Multiple Range Test menunjukkan bahwa terdapat perbedaan yang signifikan antara biskuit $\mathrm{P} 1$ dengan $\mathrm{P} 3$ ( $\mathrm{p}=0,017)$. 
Biskuit yang memiliki proporsi tepung terigu yang paling sedikit memiliki kadar abu yang paling rendah, hal ini karena kadar tepung terigu memiliki kadar abu lebih rendah daripada kadar air tepung kacang hijau dan tepung ikan tuna. Tepung kacang hijau dan tepung ikan tuna yang memiliki kadar abu yang tinggi yaitu sebesar 2,7 gram/ 100 gram bahan (Susanto dan Saneto, 1994) dan 3,45 gram/ 100 gram bahan (Sahril dan Lekahena, 2015). Sehingga biskuit yang memiliki proporsi tepung kacang hijau dan tepung ikan tuna paling banyak akan memiliki kadar abu yang tinggi. Hal tersebut sejalan dengan penelitian Ratnasari et al. (2015) bahwa biskuit substitusi tepung kacang hijau dengan proporsi yang lebih banyak memiliki kadar abu yang paling tinggi. Demikian juga dengan penelitian Agung et al. (2019) menunjukkan bahwa semakin meningkat proporsi substitusi tepung kacang hijau dapat meningkatkan kadar abu produk bagea.

\section{Kadar protein}

Kadar protein biskuit PMT Ibu Hamil berkisar antara 10,7-11,4 gram/ 100 gram biskuit. Kadar protein tersebut telah memenuhi syarat kadar protein biskuit berdasarkan mutu biskuit SNI No. 01-29731992 yaitu minimum 9 gram/100 gram biskuit.

Kadar protein biskuit PMT ibu hamil mengalami peningkatan, biskuit yang memiliki kadar protein paling tinggi adalah P3 (11,7 gram/100 gram biskuit) dan yang paling rendah yaitu P1 (10,7 gram/100 gram biskuit). Berdasarkan hasil analisis statistik One Way Anova pada tingkat kepercayaan 95\% menunjukkan bahwa substitusi tepung kacang hijau dan tepung ikan tuna memberikan pengaruh yang signifikan $(\mathrm{p}=0,034)$ terhadap kadar protein biskuit. Analisis lebih lanjut dengan Duncan Multiple Range Test menunjukkan bahwa terdapat perbedaan yang signifikan antara biskuit $\mathrm{P} 1$ dengan $\mathrm{P} 3(\mathrm{p}=0,032)$.

Tepung kacang hijau dan tepung ikan tuna memiliki kadar protein yang tinggi yaitu sebesar 25,14 gram/ 100 gram bahan (Susanto dan Saneto, 1994) dan 79,8 gram/
100 gram bahan (Sahril dan Lekahena, 2015). Sehingga biskuit dengan proporsi kacang hijau paling tinggi yaitu P3 memiliki kadar protein yang paling tinggi. Hal tersebut sependapat dengan penelitian Wardani et al. (2018) bahwa bolu kukus substitusi tepung kacang hijau dengan proporsi yang lebih banyak memiliki kadar protein yang paling tinggi. Menurut Winarno (2004), konsumsi protein kurang pada ibu hamil dalam waktu yang lama dapat memecah simpanan protein tubuh akibatnya tubuh menjadi kurus. Apabila simpanan protein tubuh digunakan untuk metabolisme energi dapat mengganggu pertumbuhan dan perkembangan janin di dalam rahim ibu. Wanita yang sedang hamil membutuhkan protein tambahan dibandingkan dengan wanita yang tidak hamil. Hasil penelitian Pratiwi (2017) menunjukkan bahwa terdapat hubungan antara asupan protein dengan kadar hemoglobin pada ibu hamil di Kabupaten Sukoharjo, asupan protein pada ibu hamil penting untuk meningkatkan penyerapan zat besi dan dapat meningkatkan kadar hemoglobin ibu hamil. Kadar protein juga berkaitan dengan status gizi bayi saat lahir, hal ini dibuktikan oleh Syari et al. (2015) yang mengatakan bahwa terdapat hubungan yang signifikan antara asupan protein ibu saat hamil dengan berat badan bayi saat lahir.

Biskuit dengan substitusi tepung kacang hijau dan tepung ikan tuna memiliki kadar protein yang dapat memenuhi kebutuhan ibu hamil. Kacang hijau mengandung $20-25 \%$ protein. Protein kacang hijau kaya asam amino leusin, arginin, isoleusin, valin, dan lisin. Keseimbangan asam amino pada kacang hijau mirip dan sebanding dengan kedelai. Sedangkan ikan tuna merupakan jenis ikan dengan kandungan protein tinggi, berkisar antara $22,6-26,2$ g/100 g. Kadar protein pada ikan tuna hampir dua kali kadar protein telur ayam. Kandungan protein yang terdapat pada biskuit sangat penting untuk sel, pertumbuhan dan perkembangan janin. 


\section{Kadar lemak}

Kadar lemak biskuit PMT Ibu Hamil berkisar antara 12,6-13,9g/ 100g biskuit. Kadar lemak tersebut telah memenuhi syarat kadar lemak biskuit berdasarkan mutu biskuit SNI No. 01-2973-1992 yaitu minimum 9,5 gram/100g biskuit.

Kadar lemak biskuit PMT ibu hamil mengalami penurunan, kadar lemak biskuit yang paling rendah adalah P3 (12,6 gram/ 100 gram biskuit) dan yang paling tinggi adalah P1 (13,9 gram/ 100 gram biskuit). Berdasarkan hasil analisis statistik One Way Anova pada tingkat kepercayaan 95\% menunjukkan bahwa substitusi tepung kacang hijau dan tepung ikan tuna memberikan pengaruh yang signifikan $(\mathrm{p}=0,010)$ terhadap kadar lemak biskuit. Analisis lebih lanjut dengan Duncan Multiple Range Test menunjukkan bahwa terdapat perbedaan yang signifikan antara biskuit P1 dengan P2 $(\mathrm{p}=0,019)$ dan $\mathrm{P} 1$ dengan P3 ( $p=0,013)$.

Biskuit dengan proporsi tepung ikan tuna lebih banyak memiliki kadar lemak yang paling tinggi. Hal ini disebabkan karena bahan yang digunakan yaitu tepung ikan tuna memiliki kadar lemak yang tinggi sebesar 9 gram/ 100gram bahan (Sahril dan Lekahena, 2015). Selain itu biskuit dengan proporsi tepung kacang hijau lebih banyak tidak mempengaruhi kadar lemak biskuit. Tepung kacang hijau memiliki kadar lemak yang rendah sebesar 1,34 gram/ 100 gram bahan (Susanto dan Saneto, 1994). Hal tersebut sependapat dengan penelitian Ratnasari et al. (2015) bahwa biskuit substitusi tepung kacang hijau dengan proporsi yang lebih banyak memiliki kadar lemak yang paling rendah.

Biskuit dengan substitusi tepung kacang hijau dan tepung ikan tuna memiliki kadar lemak yang dapat memenuhi kebutuhan ibu hamil. Lemak kacang hijau sebagian besar tersusun atas asam lemak jenuh oleat $(20,8 \%)$, linoleat $(16,3 \%)$, linolenat (37,5\%). Sedangkan Ikan tuna tinggi asam lemak omega-3, kadarnya 28 kali lebih banyak dari pada ikan air tawar. asam lemak esensial sangat diperlukan bagi pertumbuhan dan perkembangan bayi dan anak, selain itu lemak dapat digunakan sebagai cadangan energi saat melahirkan.

\section{Kadar karbohidrat}

Kadar karbohidrat biskuit PMT Ibu Hamil berkisar antara 70,4-72,2g /100 g biskuit. Kadar karbohidrat tersebut telah memenuhi syarat kadar karbohidrat biskuit berdasarkan mutu biskuit SNI No. 01-29731992 yaitu minimun 70 gram/100 gram biskuit.

Kadar karbohidrat biskuit PMT ibu hamil mengalami penurunan, kadar karbohidrat paling rendah adalah P3 $(69,8$ gram/100 gram biskuit) dan kadar tertinggi adalah P1 (71,5 gram/ 100 gram biskuit). Berdasarkan hasil analisis statistik One Way Anova pada tingkat kepercayaan 95\% menunjukkan bahwa substitusi tepung kacang hijau dan tepung ikan tuna memberikan pengaruh yang tidak signifikan $(\mathrm{p}=0,261)$ terhadap kadar karbohidrat biskuit.

Tepung terigu merupakan sumber makanan yang tinggi karbohidrat sebesar 77,3 gram/ 100 bahan, sedangkan kadar karbohidrat pada tepung kacang hijau dan tepung ikan tuna lebih rendah dari tepung terigu sebesar 70,28 gram/ 100 gram bahan (Susanto dan Saneto, 1994) dan 4,64 gram/ 100gram bahan (Sahril dan Lekahena, 2015). Sehingga biskuit dengan proporsi tepung terigu paling banyak akan memiliki kadar karbohidrat yang tinggi. Hal tersebut sependapat dengan penelitian Ratnasari et al. (2015) bahwa biskuit substitusi tepung terigu dengan proporsi yang lebih banyak dibandingkan dengan tepung kacang hijau memiliki kadar karbohidrat yang paling tinggi.

Selain itu penurunan karbohidrat dipengaruhi oleh komponen nutrisi lainnya, yaitu kadar air, abu, protein dan lemak. Kadar karbohidrat dihitung secara by difference sehingga semakin rendah komponen kadar air, abu, protein dan lemak makan kadar karbohidrat akan semakin tinggi. Begitu juga sebaliknya semakin tinggi komponen kadar air, abu, protein dan lemak 
makan kadar karbohidrat akan semakin rendah.

Kadar karbohidrat biskuit PMT terendah (69,8 gram/ 100 gram biskuit) terdapat pada taraf perlakuan P3 dengan proporsi terigu sebesar $55 \%$ yang memiliki kadar protein sebesar 11,7 gram/ 100 gram biskuit dan kadar lemak sebesar 12,6 gram/ 100 gram biskuit. Sedangkan Kadar karbohidrat biskuit PMT tertinggi (74,2 gram/ 100 gram biskuit) terdapat pada taraf perlakuan P1 dengan proporsi terigu sebesar $75 \%$ yang memiliki kadar protein sebesar 10,7 gram/ 100 gram biskuit dan kadar lemak sebesar 13,9 gram/ 100 gram biskuit.

Biskuit dengan substitusi tepung kacang hijau dan tepung ikan tuna memiliki kadar karbohidrat yang dapat memenuhi kebutuhan ibu hamil. Karbohidrat merupakan bagian terbesar pada kacang hijau yaitu 55,5\% sehingga dapat digunakan sebagai sumber energi. Karbohidrat pada kacang hijau tersusun atas pati, gula, dan serat kasar. Pati kacang hijau terdiri dari $28,8 \%$ amilosa dan $71,2 \%$ amilopektin, Sedangkan ikan tuna memiliki karbohidrat yang rendah.

\section{Nilai energi}

Nilai energi biskuit PMT Ibu Hamil berkisar antara 440-450 / 100 g biskuit. Nilai energi tersebut telah memenuhi syarat nilai energi biskuit berdasarkan mutu biskuit SNI No. 01-2973-1992 yaitu minimun 400 gram/100 gram biskuit.

Nilai energi biskuit PMT ibu hamil mengalami penurunan, nilai energi paling rendah terdapat pada P3 (439,9 gram/ 100 gram bahan) dan nilai energi yang paling tinggi terdapat pada P1 (450 gram/100 gram bahan). Berdasarkan hasil analisis statistik One Way Anova pada tingkat kepercayaan 95\% menunjukkan bahwa substitusi tepung kacang hijau dan tepung ikan tuna memberikan pengaruh yang signifikan $(\mathrm{p}=0,022)$ terhadap nilai energi biskuit. Analisis lebih lanjut dengan Duncan Multiple Range Test menunjukkan bahwa terdapat perbedaan yang signifikan antara biskuit P1 dengan P2 $(\mathrm{p}=0,041)$ dan $\mathrm{P} 1$ dengan $\mathrm{P} 3(\mathrm{p}=0,029)$.
Biskuit yang diberikan proporsi tepung terigu dan tepung ikan tuna lebih sedikit memiliki nilai energi yang paling rendah (P3). Selain dipengaruhi oleh proporsi substitusi, penurunan nilai energi juga dipengaruhi kandungan zat gizi penghasil energi yaitu protein, lemak, dan karbohidrat. Hal ini sesuai dengan pernyataan Almatsier (2010), bahwa kandungan protein, lemak, dan karbohidrat suatu bahan makanan menentukan nilai energinya.

\section{Kadar zat besi}

Kadar zat besi biskuit PMT Ibu Hamil berkisar antara 19,7-22,3g / $100 \mathrm{~g}$ biskuit. Kadar zat besi tersebut telah memenuhi kebutuhan zat besi ibu hamil yaitu 20 gram/ 100 gram biskuit.

Kadar zat besi biskuit PMT ibu hamil mengalami peningkatan, kadar zat besi tertinggi terdapat pada P3 (22,3 gram/ 100 gram bahan) dan kadar zat besi terendah terdapat pada P1 (19,7 gram/ 100 gram biskuit). Berdasarkan hasil analisis statistik One Way Anova pada tingkat kepercayaan 95\% menunjukkan bahwa substitusi tepung kacang hijau dan tepung ikan tuna memberikan pengaruh yang signifikan ( $\mathrm{p}=0,012)$ terhadap kadar zat besi biskuit. Analisis lebih lanjut dengan Duncan Multiple Random Test menunjukkan bahwa terdapat perbedaan yang signifikan antara biskuit P1 dengan P2 $(\mathrm{p}=0,042)$ dan $\mathrm{P} 1$ dengan P3 ( $p=0,011)$.

Biskuit yang diberikan proporsi tepung kacang hijau dan tepung ikan tuna lebih banyak (P3) memiliki kadar zat besi yang lebih tinggi. Hal ini disebabkan karena bahan yang digunakan yaitu tepung kacang hijau dan tepung ikan tuna memiliki kadar zat besi yang tinggi sebesar 7,82 gram/ 100 gram bahan (Susanto dan Saneto, 1994) dan 9 gram/100gram bahan (Sahril dan Lekahena, 2015).

Semakin Tinggi komponen kadar zat besi maka kadar abu akan semakin tinggi, begitu juga sebaliknya. Kadar zat besi biskuit PMT tertinggi (22,3 gram/ 100 gram bahan) terdapat pada taraf perlakuan P3 dengan proporsi terigu sebesar 55\% yang memiliki kadar abu sebesar 2,7 gram/ 100 gram bahan, 
sedangkan kadar zat besi biskuit PMT terendah (19,7 gram/ 100 gram bahan) terdapat pada taraf perlakuan P1 dengan proporsi terigu sebesar $75 \%$ yang memiliki kadar abu sebesar 2,2 gram/ 100 gram bahan.

Ketika ibu hamil mengalami anemia maka akan mempengaruhi pertumbuhan, pembentukan, dan perkembangan janin menjadi kurang optimal, dan akan berdampak cacat bawaan pada bayi dan kematian bayi karena BBLR (Dewi et al., 2013). Dampak jangka panjangnya adalah balita atau baduta yang dilahirkan akan mengalami stunting, dan memiliki tingkat kecerdasan rendah. Hasil penelitian Prabandari et al. (2016) di Boyolali menyatakan bahwa anemia pada ibu hamil trimester III berpotensi mempengaruhi status gizi bayi lahir, artinya semakin tinggi kadar $\mathrm{Hb}$ ibu hamil trimester III maka semakin baik pula status gizi bayi lahir. Selanjutnya penelitian Sairuroh (2019) menunjukkan terjadi peningkatan kadar hemoglobin ibu hamil KEK yang mendapatkan PMT.

\section{Mutu organoleptik}

Tabel 4. Mutu organoleptik biskuit dalam 100 gram biskuit

\begin{tabular}{lccc}
\hline Kadar Zat Gizi & $\begin{array}{c}\text { P1 } \\
(\mathbf{7 5 : 1 5 : 1 0 )}\end{array}$ & $\begin{array}{c}\text { P2 } \\
(\mathbf{6 5 : 2 9 : 6 )}\end{array}$ & $\begin{array}{c}\text { P3 } \\
(\mathbf{5 5 : 4 1 : 4 )}\end{array}$ \\
\hline Warna & $3,24^{\mathrm{a}}$ & $2,96^{\mathrm{a}}$ & $2,96^{\mathrm{a}}$ \\
Aroma & $2,88^{\mathrm{a}}$ & $3,36^{\mathrm{b}}$ & $3,36^{\mathrm{c}}$ \\
Rasa & $2,92^{\mathrm{a}}$ & $3,52^{\mathrm{a}}$ & $3,24^{\mathrm{a}}$ \\
Tekstur & $3,24^{\mathrm{a}}$ & $3,04^{\mathrm{a}}$ & $2,88^{\mathrm{a}}$ \\
\hline
\end{tabular}

Warna

Tingkat kesukaan panelis terhadap warna biskuit berkisar antara 2,96-3,24. Warna biskuit yang dihasilkan yaitu kuning kehijauan dengan kepekatan yang berbedabeda setiap taraf perlakuan. Warna kuning pada biskuit PMT ibu hamil disebabkan karena reaksi reaksi karamelisasai yang timbul bila gula dipanaskan serta warna gelap yang timbul akibat adanya reaksi maillard, jika terjadi reaksi antara gugus amino protein dengan gugus karbonil gula pereduksi (Winarno, 2004). Sedangkan warna kehijauan pada biskuit disebabkan karena penambahan tepung kacang hijau, warna hijau di kacang hijau didapatkan karena terdapat pigmen klorofil.

Hasil analisis statistik Kruskall Wallis pada tingkat kepercayaan 95\% menunjukkan bahwa substitusi tepung kacang hijau dan ikan tuna memberikan pengaruh yang tidak signifikan $(p=0,166)$ terhadap warna biskuit PMT ibu hamil

Aroma

Tingkat kesukaan panelis terhadap aroma biskuit berkisar 2,88-3,36. Tingkat kesukaan panelis terhadap aroma biskuit PMT yang tertinggi ada pada taraf perlakuan
P3, yaitu aroma khas kacang hijau. Hal tersebut disebabkan substitusi tepung kacang hijau yang lebih banyak dan proporsi tepung ikan tuna yang rendah menyebabkan peningkatan kesukaan panelis pada aroma biskuit.

Hasil analisis statistik Kruskall Wallis pada tingkat kepercayaan $95 \%$ menunjukkan bahwa substitusi tepung kacang hijau dan ikan tuna memberikan pengaruh yang signifikan $(\mathrm{p}=0,009)$ terhadap aroma biskuit PMT ibu hamil. Analisis lebih lanjut dengan Mann-Whitney menunjukkan bahwa terdapat perbedaan yang signifikan terhadap tingkat kesukaan aroma P1, P2, dan P3.

\section{Rasa}

Tingkat kesukaan panelis terhadap rasa biskuit berkisar 2,92-3,52. Tingkat kesukaan panelis terhadap rasa biskuit PMT yang tertinggi ada pada taraf perlakuan P3, yaitu gurih, manis, dan rasa khas kacang hijau. Hal tersebut disebabkan substitusi tepung kacang hijau yang lebih banyak menyebabkan peningkatan kesukaan panelis pada rasa biskuit. Rasa bahan pangan berasal dari bahan itu sendiri dan apabila telah melaui proses pengolahan maka rasanya akan dipengaruhi oleh bahan-bahan yang 
ditambahkan selama proses pengolahan. Menurut Winarno (2004) menyatakan ada beberapa faktor yang dapat mempengaruhi rasa, antara lain senyawa kimia, suhu, konsentrasi, dan interaksi komponen rasa yang lain.

Hasil analisis statistik Kruskall Wallis pada tingkat kepercayaan 95\% menunjukkan bahwa substitusi tepung kacang hijau dan ikan tuna memberikan pengaruh yang tidak signifikan $(p=0,195)$ terhadap rasa biskuit PMT ibu hamil.

\section{Tekstur}

Tingkat kesukaan panelis terhadap tekstur biskuit berkisar 2,88-3,24. Tingkat kesukaan panelis terhadap tekstur biskuit PMT yang tertinggi ada pada taraf perlakuan P1, yaitu renyah. Hal tersebut disebabkan substitusi tepung kacang hijau yang lebih sedikit menyebabkan peningkatan kesukaan panelis pada rasa biskuit. Apabila ditinjau dari modus tingkat kesukaan rasa P1 adalah suka dikarenakan tekstur sangat renyah.

Hasil analisis statistik Kruskall Wallis pada tingkat kepercayaan $95 \%$ menunjukkan bahwa substitusi tepung kacang hijau dan ikan tuna memberikan pengaruh yang tidak signifikan $(p=0,796)$ terhadap tekstur biskuit PMT ibu hamil.

\section{Taraf perlakuan terbaik}

Dari hasil perhitungan taraf perlakuan terbaik dihasilkan nilai hasil $(\mathrm{NH})$ tertinggi yaitu pada $\mathrm{P} 2$ dengan total nilai 0,560 .

\section{KESIMPULAN}

Biskuit PMT Ibu hamil dengan substitusi tepung kacang hijau dan tepung ikan tuna memberikan pengaruh yang signifikan terhadap kadar air, kadar abu, kadar protein, kadar lemak, zat besi dan nilai energi. Namun memberikan pengaruh yang tidak signifikan terhadap kadar karbohidrat. Biskuit PMT Ibu hamil dengan substitusi tepung kacang hijau dan tepung ikan tuna memberikan pengaruh yang signifikan terhadap tingkat penerimaan aroma, namun memberikan pengaruh yang tidak signifikan terhadap tingkat penerimaan warna, rasa, dan tekstur. Taraf perlakuan terbaik yaitu P2 (65:29:6) dengan total nilai 0,560.

\section{Saran}

1. Biskuit substitusi tepung kacang hijau dan tepung ikan tuna pada taraf perlakuan P2 dapat dijadikan salah satu makanan tambahan untuk ibu hamil karena merupakan taraf perlakuan terbaik yang memiliki nilai energi, protein, lemak, karbohidrat dan zat besi yang dapat menambah kebutuhan ibu hamil serta mutu organoleptik yang disukai.

2. Biskuit PMT ibu hamil yang disarankan untuk dikonsumsi adalah 65 gram per satu kali saji, hal ini dapat memenuhi $10 \%$ kebutuhan ibu hamil.

\section{DAFTAR PUSTAKA}

Agung, A. P., Tamrin, T., \& Rejeki, S. (2019). Kajian pengembangan tepung kacang hijau (Vigna Radiata L) sebagai bahan substitusi bagea untuk memenuhi angka kecukupan zat besi (Fe) remaja putri. Jurnal sains dan teknologi pangan, 3(6). Diambil dari http://ojs.uho.ac.id/index.php/jstp/artic le/view/5384

Almatsier, S. (2010). Prinsip dasar ilmu gizi. Jakarta: PT. Gramedia.

AOAC. (2005). Official of analysis of the association of official analytical chemistry. Arlington: AOAC Inc.

Badan Standar Nasional. (1992). SNI 012973-1992, 2907_SNI 01-2973-1992biskuit

BPS. (2015). Profil Penduduk Indonesia Hasil Supas 2015. Diakses Akses tanggal 27 Juli 2018

Dewi, A. B., Pujiastuti, N., \& Fajar, I. (2013). Ilmu gizi untuk praktisi kesehatan. Yogyakarta: Graha Ilmu.

Depkes RI. (2013). Angka Kecukupan Gizi. Jakarta: Kementrian Kesehatan.

Ide, P. (2013). Agar Otak Sehat 2. Elex Media Komputindo.

Kemenkes RI. (2015). Pedoman Gizi Ibu Hamil dan Pengembangan Makanan Tambahan Ibu Hamil Berbasis 
Pangan Lokal. Jakarta: Kementrian Kesehatan.

Kemenkes RI. (2016). Standart Produk Suplementasi Gizi. Jakarta: Kementrian Kesehatan.

Kementerian Kesehatan RI. (2017). Petunjuk Teknis Pemberian Makanan Tambahan Balita, Ibu Hamil, dan Anak Sekolah. Jakarta: Kementerian Kesehatan RI

Kementerian Kesehatan RI. (2018). Profil Kesehatan Penduduk Indonesia. Diakses 20 Juni 2018

Komah, R. I. \& Kristiastuti, D. (2013). Pengaruh substitusi tepung kacang hijau terhadap tingkat kesukaan kue jongkong. Jurnal Pangan, 2, 18-24.

Nurdiani, R. (2003). Pemanfaatan tepung tulang ikan patin (Pangasius sutchi) untuk meningkatkan kandungan kalsium susu kacang hijau (Skripsi). IPB Bogor, Bogor.

Prabandari, Y., Hanim, D., AR, R. C., \& Indarto, D. (2016). Hubungan kurang energi kronik dan anemia pada ibu hamil dengan status gizi bayi usia 612 bulan di kabupaten Boyolali. Penelitian Gizi dan Makanan, 39(1), 1-8.

Pratiwi, I. Y., Puspitasari, D. I., Gz, S., \& Nutr, M. (2017). Hubungan asupan protein dan status gizi dengan kadar hemoglobin ibu hamil di desa Demakan kecamatan Mojolaban kabupaten Sukoharjo (Desertasi). Universitas Muhammadiyah Surakarta.

Putri, R. H., \& Sofiyatin, R. (2019). Pemberian biskuit berbasis bahan pangan lokal untuk meningkatkan berat badan dan LiLA Ibu hamil KEK (Kurang Energi Kalori). Jurnal Kesehatan Prima, 13(1), 32-40.

Ratnasari, D., Yunianta, Y., \& Maligan, J. M. (2015). Pengaruh tepung kacang hijau, tepung labu kuning, margarin terhadap fisikokimia dan organoleptik biskuit. Jurnal Pangan dan Agroindustri, 3(4).
Sahril, D. F., \& Lekahena, V. N. (2015). Pengaruh konsentrasi asam asetat terhadap karakteristik fisiokimia tepung ikan dari daging merah ikan tuna. Agrikan: Jurnal Agribisnis Perikanan, 8(1), 69-76.

Sairuroh, S. (2019). Dampak pemberian biskuit pada ibu hamil berisiko kekurangan energi kronis terhadap kadar hemoglobin. Media Kesehatan Masyarakat Indonesia, 18(2), 1-6.

Sidabutar, W.D.R, Nainggolan, R.J dan Ridwansyah. (2013). Kajian substitusi tepung talas dan tepung kacang hijau terhadap mutu cookies. Jurnal Rekayasa Pangan, 1(4), 67-75.

Soekarto, S. T. (1985). Penilaian organoleptik: untuk industri pangan dan hasil pertanian. Jakarta: Bhratara Karya Aksara.

Sukmawati, S., Hendrayati, H., Chaerunnimah, C., \& Nurhumaira, N. (2018). Status gizi ibu saat hamil, berat badan lahir bayi dengan stunting pada balita usia 06-36 bulan di Puskesmas Bontoa. Media Gizi Pangan, 25(1), 18-24.

Susanto, T., \& Saneto, B. (1994). Teknologi pengolahan hasil pertanian. Surabaya: Bina Ilmu.

Syari, M., Serudji, J., \& Mariati, U. (2015). Peran asupan zat gizi makronutrien ibu hamil terhadap berat badan lahir bayi di Kota Padang. Jurnal Kesehatan Andalas, 4(3).

Wahyu Ningrum, Ema. (2017). Korelasi antara status gizi KEK dengan berat badan dan panjang badan bayi baru lahir. Jurnal Viva Medika, 11(2), 1-9

Wardani, D. H. K., \& Pramudya Kurnia, S. T. P. (2018). Pengaruh substitusi tepung kacang hijau (Vigna Radiata L.) terhadap kadar protein dan daya terima bolu kukus (PhD Thesis). Universitas Muhammadiyah Surakarta.

Winarno, F. G. (2004). Kimia pangan dan gizi. Cetakan kesebelas. Jakarta: PT. Gramedia. 